\title{
Role of ICTs in Promoting Learner Independence and Motivation in English Language Classes
}

\author{
Khem Raj Joshi \& Guru Prasad Poudel \\ Teaching Assistant \\ Department of English Education \\ Tribhuvan University, Kathmandu, Nepal
}

\begin{abstract}
This article builds up on an action research which was carried out mainly with two major purposes: to investigate learner perceptions and attitudes in the use of ICTs in English language classes; and to examine the role of ICTs in promoting the learner independence and motivation. The population of the study consisted of all the students from the Department of English Education, Central Department of Education, Kirtipur. The area was purposively selected; we have been teaching in the same place for seven years. The participants were 37 students who were also purposively selected. Among them, only 15 students were invited to a focused group discussion (FGD). However, all the students participated in the intervention for the whole semester. The intervention was implemented during the instruction. The major ICT tools adopted for the study were: web sites, e-mails and multimedia. We administered three progress tests to assess their progress in terms of independence and motivation. The findings of this research show that the learners are well motivated and positive in the use of ICTs in language teaching
\end{abstract}

Keywords: ICT, Independence, Motivation, Intervention

\section{Introduction}

Information Communication Technologies (ICTs) have significant impact on all aspects of human life. ICT tools have become one of the basic building blocks of modern society within a very short time (Daniels, 2002). Our teaching learning procedures, learner attitudes, pedagogical activities and motivation also have to bear such impacts. With these changes, teachers also need to adjust and adapt ourselves to address students' needs. Teachers cannot drag students with the same traditional means. Further, if teachers observe student activities into the classroom (such as in Tribhuvan University), there is a low participation of the students in many respects. More noticeably, there is a tendency of greater dependence on teachers and the limited information that they provide. This has led to the lower confidence on the part of the learners. ICTs have the potential to innovate, accelerate, enrich, and deepen skills; to motivate and engage students; and to help relate school experience to work practices (Davis \& Tearle, 1999). 


\section{Statement of the Problem}

The needs for the use of ICTs are continuously and rapidly growing in the field of language teaching. In the context like ours, to cope with the current challenges caused by the traditional modes of teaching, it can work as one of the best tools. Though ICT is not a method in itself, it can be used to modify them to make our teaching learning activities more motivating and effective to ensure greater participation of the learners on their own. ICTs have also been a great part of our experiences but their use is not taken seriously in language classroom. Secondly, they are not brought into the classrooms in appropriate forms. Learners are growing more like the parasites due to the use of traditional 'jugs and mugs theory' (Williams and Burden, 1997) in language teaching. Therefore, in such case, ICTs use can have an important role to support their learning.

\section{Review of Related Literature}

In order to understand the issue of the study in advance, we went through some theoretical underpinnings on ICTs, learner independence and learning motivation, which have been discussed in this section.

ICT-integrated instruction is a way of learning in an interactive way with an excessive use of ICT based tools and technologies including internet, email, websites, blogs and wikis (Davies, 2013, p.14). It includes learning interactively with an online support and use of techno-based tools between teachers and learners, and peers. The $21^{\text {st }}$ century is an era of science and technology (Lightbown \& Spada, 2013). Teachers can integrate technologies and use e-devices to develop and tailor instructional materials to better meet individual students' needs. At present, e-devices have impact in all aspects of life; so in the modern world of computer, the internet and other e-forms have become an integral part of ELT (Gide, 2014, p.29). As the recent innovations, Mobile Assisted Language Learning (MAAL), Computer Assisted Language Learning (CALL), Technology Enhanced Learning (TELL), Blended learning and E-learning have been increasingly used in English language classroom (Holmes \& Gardner, 2016). The value of ICTs for language learning is widely accepted, albeit in some cases with caution (Warschauer \& Ware, 2008). In the context of developing countries, ICTs are often seen as empowering tools which provide people with access to opportunities and choices that were hitherto not available; however, e-devices for English language teaching and learning are still an emerging field in developing countries (Duff, 2015).

Some modern electronic devices such as computer, television, mobile phone, multimedia and web-based applications have played vital roles in language teaching. They help to teach language more effectively and appropriately. It is claimed that most of the teachers in urban areas have been using various technologies in the classroom (Ulbricht, 2016). There is a growing tendency of using ICT in language teaching and learning with the help of e-devices. It can be taken as a positive signal towards e-learning. However, there exist many challenges in implementing e-devices. The problems are related to attitudes in the use; challenges teachers face while going through them in the classes; and the strategies to be chosen for their effective uses (Shrestha, 2011). 
Technological innovations in language teaching are being used as for learners' motivation in learning at present because traditional methods of imparting higher education have become less motivating. Here, technology plays an important role in bringing innovation and motivation for the learners (Stockwell, 2016). The word 'technology' in teaching includes the use of devices such as computer, mobile phones, radio, and television and satellite system. Now, the role and use of technology as a tool for teaching English is increasing to create both independent and collaborative learning environment in which students can learn English with much ease. For teachers, ICT tools are professional resources: a mode of classroom delivery and a source of valid and valuable text types. For students, it provides opportunities to communicate more effectively and to develop literacy skills including skills in critical literacy. It is a valuable tool for researching, composing and responding, viewing and representing in English (Stockwell, 2016). The teacher can use a mobile to get access on email, social networking sites, messenger, mobile apps, online dictionaries, radio, television, cable, tabs, CDs, DVDs and other highly accessible data based sub-systems in language teaching and learning in order to motivate the learners (Pears, 2015).

Motivating students is a great challenge throughout education. Although there are no clear cut solutions, there are several strategies to help teachers with the dilemma (Linnenbrink and Pintrich, 2003). Motivation arouses interests and gets humans going to achieve an expected goal. Teachers are always looking to see what motivates their students. Motivation is the key to academic success as well as promoting lifelong learning (Sanacore, 2008). The reluctance to learn must be turned into the want to learn.

The learners may be interested or less motivated in learning depending upon the content, materials, and methods of teaching them. Sometimes we can get them being reluctant in learning. One common thread among reluctant learners is their perception of themselves, known as selfefficacy (Sanacore, 2008). If their self-efficacy is low, then their motivation to perform will be low. Students are motivated when they feel excited about a task or feel that what they are doing is worthwhile (Linnenbrink and Pintrich, 2003). Teachers must adjust their teaching to match the motivations of their students. In order to motivate, teachers must encourage and challenge their students with an application of ICTs (Sanacore, 2008). Students presented with too easy or too difficult material will eventually become bored and unmotivated. So, we can bring task variation and modification by means of ICTs in the classroom.

Creating activities that students enjoy and respond to is a challenging task for teachers of all subjects. Introducing technology infused lessons may prove to be a beneficial motivator for every grade level. Digital natives respond well to technology infused activities because of their familiarity with technology (Prensky, 2001). Technology and teacher motivation have positive effects on students (Atkinson, 2000). It is because students respond positively to technology and are motivated by technology, teachers should make conscious efforts to create activities that encompass some form of technological tool. Motivated students will be more likely to perform at their highest levels because of the opportunities that their teachers have made available and such opportunities can be created via ICTS. Thus, ICTs have become motivating tools to both the 
teachers and students. In this regards, Gide (2014, pp. 37-43) says that they are really motivating for creating no boundary and no restrictions in learning, providing more fun in learning, being cost effective, making learning ease by creating flexibility and the ability to remotely access classroom in the students own time, keeping learners engaged and becoming a self-assessment tool. Besides this, the use of ICT in learning language in daily life is to: develop intercultural communication skills, prepare for internationalism, get opportunities to study content through different perspectives, access subject-specific target language terminology, improve overall target language competence, develop oral communication and socialization skills, diversify methods and forms of classroom practice, promote autonomous learning, make time flexible learning, learn language implicitly, develop more practical aspect by using it in different context and increase motivation (Linnenbrink and Pintrich, 2003).

In the same way, learner autonomy and learner independence can be sought in the classroom through the integration of ICTs in classroom intervention and in students' self-study. Traditional educational practices no longer provide students with all the necessary skills to be independent in learning. When ICT tools are widely used at all levels of education, the students become more autonomous in finding out the required information to them. Ajayi (2008) noted that 'today's schools are organized around yesterday's ideal, yesterday's needs, and yesterday resources were not even doing very well due to the application of modern sophisticated tools like email. Mallow (2009) in a study on assessment of secondary students' use of ICT, found that students were highly enthusiastic to learn the skills and knowledge in the use of computer and software and the result is increasing independence in utilizing ICT tools for communication. The study of Aramide (2004) showed that there were not enough learning opportunities for learners in the use of ICT in a classroom environment. Similarly, the study of Poly (2011) concludes that technology has been shown to positively influence student learning when students explore technology-rich tasks that simultaneously require them to use higher-order thinking skills (HOTS), such as analyzing or evaluating information or creating new representations of knowledge. We need to integrate ICTs in classroom intervention by employing needs analysis of who among them have skills to operate technologies, what type of skill does he/she need; the duration for profitable preparation. In the recent past, the government has initiated virtual programs through the use of ICTs for the students who are not able to attend face to face class in the form of open and distance education for developing learners' independence and autonomy in learning (Sharma, 2016).

\section{The Study}

This paper is based on an action research. We carried out this study mainly with two major purposes. First, it aimed to investigate the learner perceptions and attitudes in the use of ICTs in the English language classes and second, to examine the role of ICTs in promoting the learner independence and motivation. In order to achieve our goal, we went hand-in-hand for teaching, keeping records, interviewing and giving the tests. The roles were alternated in some situations we needed. The population of the study consisted of all the students from the Department of English Education, T. U., Kirtipur, Kathmandu. The area was purposively selected for that we also are the faculty members in the same place and also that we already had some experiences of the problems at that place. Most importantly, the position we hold is that action research is 
best carried out by the insiders than others. As a sample and the participants in the study, all 37 students from a section of a semester were purposively selected. Among them, only 15 students selected through simple random sampling design and the 'fish-bowl draws technique' (Kumar, 2oo5) took part in a Focused Group Discussion (FGD). The study was done so as to meet our first objective. However, all the students underwent the intervention for the whole semester (i.e. 48 teaching hours). It was done during the regular classes of the course ELT Pedagogy and Materials, i.e. three days a week and one hour each day. Before going through the intervention, the students were given a pre-test so as to see their current level of knowledge and motivation. After that, they were provided with the varieties of the materials on the course as they needed. So as to make them well resourced, the major ICT tools used were: webs, e-mails and multimedia. In the course of time, we observed them to see their independence and took three progress tests too to attain our objectives. By the end of the semester, 5 of the students were invited to an exit interview (Harry et al., 2005) for about half an hour on the voluntary basis to maintain the triangulation for achieving both the objectives.

\section{Results and Discussion}

As stated earlier, the data in this study was collected through three major tools namely, an FGD, tests and an exit interview. So, in this section, we present the discussion of the results in relation to the collected data. We gathered in-depth information from 15 of the students using a focus group discussion. To explore their perceptions and attitudes on the use of ICT in the English classes, they freely discussed on the following issues:

- $\quad$ Existing issues on ICT.

- Problems related to the teachers, teaching methods, use of ICTs, etc.

- Impacts of ICTs on learning (What they thought about their teachers' use of ICTs e.g. PowerPoint presentation).

- Subject specific use of ICTs.

- Use of ICT: Purpose and frequency.

- Challenges, difficulties, solutions and miscellaneous.

Focusing up on the above mentioned issues and areas, the students were asked to discuss and share their views. Summing up their ideas, the responses were found to be mixed. Around $70 \%$ of the students were found to be quite satisfied with the use of ICTs by their teachers especially the PowerPoint in the classes. As they reported, it was easy for the teachers and the learners both. Most of them favored it because they could use the slides as easy reading materials. However, $30 \%$ of the students were not much entertaining the use of it. This is because, the teachers used ICTs just to ease their teaching but the students were disadvantaged with it since the teachers would skip the slides so fast and just rush away with their courses. Regarding their use of technology, they most frequently used their mobile phones in searching the materials. Only $10 \%$ of them had computers at their home but more than $50 \%$ would use Wi-Fi and other kinds of Networks. Nearly, $10 \%$ still did not have their E-mail accounts though they later on 
created the new accounts. This was so upsetting that, many of them did not have good knowledge regarding how to operate most of the ICTs other than mobiles. Further, in the use of technology, their concepts seemed the subject specific that it was not to be used in some of the subjects. To validate their perceptions and attitudes, here is a part of view from one of the students who talked positively in the use of ICTs:

I think... ICT should be used. It is not only easy for teachers but also for students. If the teachers are not well prepared, they can see the slides and explain the things to us. Also, we get the slides and can use them for study during the exams. It is so short and easy... We also learn about how to use it. So, I think it is very good to use.

Here is another example of the views from the students who did not like the use of ICT the way it was used:

Sir, if you don't mind... I am not in favor of using it... You know why?... Our some of the teachers come to class without preparation and just use slides, read them... then just flash and escape and finish the course. There are some subjects where teachers have to write. So, just slides and sharing is not effective.

Similarly, test items were also used to elicit more information regarding the role of ICTs on learners' independence and motivation after the intervention through ICTs. The progress tests were taken so as to see how effective the ICTs can be in enhancing learners' autonomy in seeking and getting information for their study purpose. The tests included the content based questions on which students had to write the answer via searching more recent and relevant literature from internet-based resources. The websites were given to them including the related authors. The students were instructed to make their write up with reference to the given authors and sources. In the beginning, i.e. before the intervention, they were given a pre-test. We conducted a series of three progress tests. When we talked of tests to them, initially they felt so tedious to attend the test. However, after the first progress test and after they received the materials they needed, they were found so eager to take the tests. They gradually thought that it would improve them and it was all for their betterment. The notable thing was that they took part actively in all the activities done with the facilitation of ICTs. They did most of the things on their own and that they were promoted to make the study independent of the teachers. In each test, they continued progressing. The total load of the test consisted of 50 marks in all the cases starting from the pretest to the last progress test. The following bar diagram shows their initial level of knowledge and motivation, and the continuum of progress: 


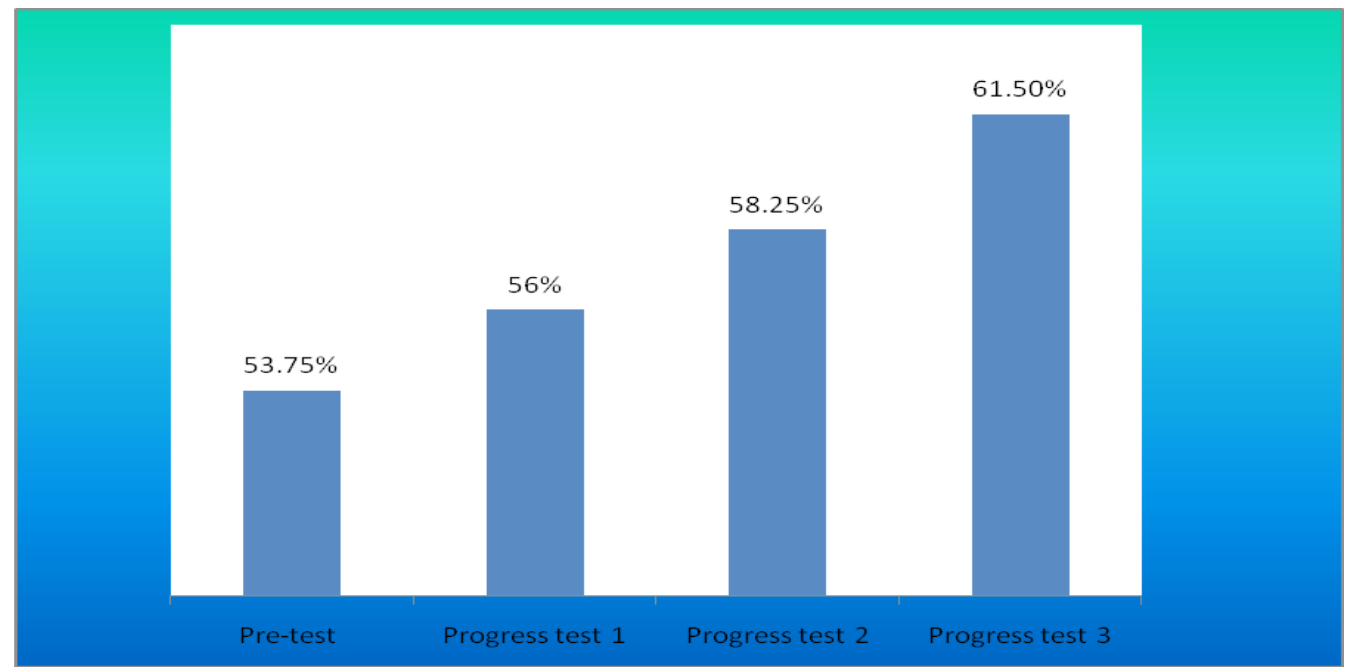

As shown in the bar chart above, in the pre-test, the average score of students was $53.75 \%$. Though it was initially measured in 50 , later it has been converted into $100 \%$. Similarly, in the progress test 1 , the total average of their score was found to be $50 \%$. It has increased by $2.25 \%$. This shows that the intervention with ICT facilitation worked well. In the same way, in the progress test 2, their mean score reached to $58.25 \%$. This time too, the progress increased by $2.25 \%$. The third progress test was taken by the end of the semester which like in earlier two was in the duration of two months. The test results showed the average score of $61.50 \%$. This was a huge progress for the students that they increased in their progress by $3.25 \%$. Thus, the entire data and the test results overtly show that the use of ICT was greatly effective. The autonomy of students is seen in relation to the increasement in their score on progress tests. The average score $3.25 \%$ in the third progress tests is a good evidence of autonomy in writing after the intervention via ICTs.

After the completion of the intervention, the students were invited to share and talk about their experiences on a voluntary basis with us during the 48 teaching hours so far we intervened them. They were so happy and quite satisfied with the ways we did with them. We invited equal number of students from among who were positive in the beginning and among from the ones who were not so happy with the use of ICTs in the classes. Every one of them had created their E-mails accounts. They all had joined to our blog during the intervention. Their conclusion was that the use of ICT really supports to the study. They were found so motivated and confident. The more interesting thing was that they had changed their mentality in the use of materials and learning. To them, learners could also learn alone even in the absence of teachers. Here is a part of interview from one of the interviewees to justify it: 
Before you taught us in this way... we thought ICT is not good. But we now understand. Its use in the way we all did is so fruitful. So, it should be used. But our some teachers should change methodology. It should not be used to finish the course but to help students this way. It is so interesting and fast catching as well. If we do this and get materials sufficient... at home... we can study ourselves...

Thus, the exit interview with the students showed that all the participants were so confident and motivated in learning. This indicates that ICT has quite a constructive role in teaching and learning of English. More importantly, it increases their level of independence and autonomy.

\section{Conclusions and Implications}

The findings of this action research show that if ICT is properly used among the students, it really has facilitating roles. The use of ICT tools has significant roles in making the learners more independent and autonomous. This works with the learners of any level. The learners are well motivated when they are provided with various materials that they need through the tools like webs, e-mails and multimedia and many more others. So, there is a dire need of providing pedagogical training for teachers and creating techno-access in the classroom. Similarly, they develop confidence for overcoming their weaknesses when we slowly motivate and try making them confident. The most notable thing that we claim through this study is that ICT is just a tool; neither a method nor an actor. It should be used as a technique to manage the knowledge and a method for searching and integrating information. Therefore, what roles it plays solely depends upon a teacher, i.e. how one employs it. If it is properly used in proper situations and understanding the learner needs, levels and interests; it proves to be a milestone to every language educators.

\section{References}

Ajayi, P.K. (2008). Managing information for school system. Lagos: University of Lagos.

Aramide, K.A. (2004). The use of information and commutation technology (ICT) by academics in Nigeria Tertiary Institution. Africa regional centre for information science. University of Ibadan: Nigeria.

Atkinson, E.S. (2000). An investigation into the relationship between teacher motivation and pupil motivation. Educational Psychology, 20 (1), 45-57.

Bello, J.B. (2000). Information and communication technologies; their role and value for science education in M. Maik \& J.O. Osborne (Eds.). Good practice in science teaching. U.S.A: Open University Press.

Daniels, J.S. (2002). Foreword in information and communication technology in education-A curriculum for schools and programme for teacher development. Paris: UNESCO.

Dare, M. (2006). A guide to effective management of public enterprises and education institutes in Nigeria. Kano: Afomats de Printers. 
Role of ICTs in Promoting Learner Independence and Motivation in English ... $/ 75$

Davies, J.M. (2013). ICTs and their significant application in teaching foreign languages. COPSSE Documents, 5 Retrieved on 9th July 2016, from: http://www.copsse. educatuon,ufl.edu/docs/Rs-5E.pdf.

Davis, N.E., \& Tearle, P. (Eds.). (1999). A core curriculum for telematics in teacher training. Retrieved on April 10, 2017 from: DOI: 10.1080/10573560390143076.

Duff, P.A. (2015). Integrated instruction in ELT. Cambridge: Cambridge University Press.

Gide, T. (2014). A study on the technology based forms of instruction at the university of Missouri. A doctoral dissertation, the Faculty of the Graduate School, University of Missouri-Columbia. Retrieved on 11th June, 2014, from: http://mospace.umsystem. edu/xmlui/bitstream/handel/10335/8898/rese arch.pdf?sequence $=3$.

Granito, M. \& Chernobilsky, E. (2012). The effect of technology on a student's motivation and knowledge retention. International Education Studies, 4, 116-125.

Harry, B. \& Klingner, J. K. (2005). Mapping the process: An exemplar of process and challenges in grounded theory analysis. Educational Researcher, 34 (11), 3-13.

Holmes, B. \& Gardner, J. (2016). E-learning: Concepts and practice. London: Sage.

Hsiao, C.H. \& Huang, T.C. (2008). A practical learning example for accounting on web-based collaborative learning. Business Education Quarterly, 118, 23-28.

Kumar, R. (2006). Research methodology (2nd ed.). Australia: Pearson Education.

Lightbown, P.M. \& Spada, N. (2013). How languages are learned (4 $\left.{ }^{\text {theds. }}\right)$. Oxford: Oxford University Press.

Linnebrink, E.A., \& Pintrich, P.R. (2003). The role of self-efficacy beliefs in student engagement and learning in the classroom. Reading \& Writing Quarterly, 19,127-133.

Nunan, D. (1993). Research methods in language learning. Cambridge: CUP.

Polly, D. (2011). Developing students' higher-order thinking skills (HOTS) through technologyrich tasks: The Influence of technological pedagogical and content knowledge (TPACK). Educational Technology, 51 (4), 20-26.

Prensky, M. (2001). Digital natives, digital immigrants. On the Horizon, 9 (5).

Sanacore, J. (2008). Turning reluctant learners into inspired learners. Clearing House: A Journal of Educational Strategies, Issues and Ideas, 82(1), 40-44.

Sharma, L.N. (2016). Open and distance education in Nepal: Prospects and challenges. T.U., Today, 16 (9).

Shrestha, P. (2011). The potential of mobile technologies for English language learning in Nepal. Journal of NELTA,16, 107-112. 
Stockwell, G. (2012d). Computer assisted language learning diversity in research and practice. Cambridge: Cambridge University Press.

Ulbricht, M. (2016). Voice of youth. Retrieved o3 November, 2017, from: http://www. mobileactive.org/case-studies/voices-youth.

Warschauer, M., \& Ware, P.D. (2008). Learning, change and power: Competing discourses of technology and literacy. In J. Coiro, K. M., C. Lankshear \& D. J. Leu (Eds.). Handbook of research on new literacies (pp.215-240). New York: Lawrence Erlbaum.

Williams, M. \& Burden, R.L. (1997). Psychology for language teachers: Social constructivist approach. Cambridge: CUP. 